\title{
QUALITY IMPROVEMENT OF EARLY CHILDHOOD EDUCATION THROUGH THE UTILIZATION OF MULTIMEDIA
}

\author{
Oleh \\ I Ketut Sudarsana \\ Institut Hindu Dharma Negeri Denpasar \\ iketutsudarsana@ihdn.ac.id
}

Diterima 21 Juni 2018, direvisi 3 Juli 2018, diterbitkan 31 Agustus 2018

\begin{abstract}
This paper aimed to describe the improvement of the quality of early childhood learning by utilizing various multimedia. The method used was a literature study by exploring various thoughts in various sources that have focused on conducting studies on early childhood education and various multimedia developed. Improving the quality of early childhood learning is very important to be performed in an effort to educate children as early as possible, so that children grow and develop as intelligent individuals, both intellectually, emotionally and spiritually. Teachers and parents need to understand and use various multimedia and guide children so that various aspects of development such as phases and tasks of child development can take place optimally.
\end{abstract}

\section{Keywords: Quality Improvement, Early Childhood Education, Multimedia}

\section{INTRODUCTION}

Children are small people who have the potential to be developed. Children have certain characteristics that are distinctive and not the same as adults, they are always active, dynamic, enthusiastic and have a high curiosity about what they see, hear, feel as if they never stop exploring and learning. Children are egocentric, have a natural sense of curiosity, are social creatures, are unique, are rich in fantasy, have short attention, and are the most useful times for learning.

Early childhood is an individual who is undergoing a process of development rapidly and fundamentally for the next life. Early childhood is at ages $0-8$ years. At this time the process of growth and development in various aspects is experiencing a fast period in the span of development of human life. The learning process as a form of treatment given to children must pay attention to the characteristics of each stage of child development.

Based on Law Number 20 of 2003 on the National Education System relating to Early Childhood Education written in article 28 paragraph 1, "Early Childhood Education is organized for children from birth to six years and is not a prerequisite for primary education". Furthermore, in Chapter 1, Article 
1, paragraph 14, it is emphasized that Early Childhood Education is a coaching effort that is shown to children from birth to six years of age, which is carried out through the provision of educational stimuli to help growth and physical and spiritual development so that children have the readiness to enter further education. Early Childhood Education is one form of education that focuses on laying the foundation towards physical growth and development (fine and rough motor coordination), intelligence (power of thought, creativity, emotional intelligence, spiritual intelligence), social-emotional (attitude and behavior and religion), language and communication, in accordance with the uniqueness and stages of development that early childhood go through.

Education for early childhood is an effort to stimulate, guide, nurture and provide learning activities that will produce children's abilities and skills. Education for early childhood is an education conducted for newborns up to eight years. In accordance with the uniqueness and growth of early childhood, the implementation of education for early childhood is adjusted to the stages of development that is passed by early childhood. PAUD efforts are not only in terms of education but also efforts to provide nutrition and child health so that in the implementation of PAUD is carried out in an integrated and comprehensive manner.

Education in early childhood basically covers all efforts and actions taken by educators and parents in the process of care, care and education in children by creating an aura and environment where children can explore experiences that provide opportunities for them to know and understand the learning experience they have gained from the environment, through observing, imitating experiments that take place repeatedly and involving all the potential and intelligence of children. Because the child is a unique person and passes through various stages of personal development, the environment that is endeavored by educators and parents who can provide opportunities for children to explore various experiences with various settings, should pay attention to the uniqueness of children and adapt to the stages of personal development. child. For example: if a child is accustomed to praying before doing activities both at home and in the school environment in a way that is most easily understood by children, then the child will be accustomed to praying even if not accompanied by parents or teachers.

Children are investments that are very important for the preparation of human resources (HR) in the future. In order to prepare quality human resources for the future, education is one of the important things to be given from an early age. Education is a future investment that is believed to improve the life of a nation. Giving more attention to early childhood to get education, is one of the right steps to prepare a superior generation that will continue the nation's struggle. Early age is a golden age which only occurs once in the development of human life. This period is at the same time a critical period in child development. If at this time children receive less attention in terms of education, care, care and health services and their nutritional needs are feared that children cannot grow and develop optimally.

Early childhood education is very important to be implemented as a basis for the formation of a full human personality, namely for the formation of character, noble character, intelligent, cheerful, skilled, and fearful of God Almighty. Early childhood education does not always have to cost a fortune or through a certain place, but early childhood education can start at home or in family education.

\section{DISCUSSION}

Child development in the first years is very important and will determine the quality in the future so that the improvement of the quality of early childhood learning by utilizing various multimedia is very important. Children are individuals who are different, unique and have their own characteristics in accordance with the stages 
of their age. Therefore, efforts to develop early childhood should be performed through learning and playing. This is because playing is a fun activity for children, through playing children have the opportunity to explore, discover, explore their feelings and be creative. In addition, playing can also help children know who they are and with whom they live and the environment in which they live or where they are.

\section{Children Characteristics}

Development is defined as a continuous and systematic change in a person from the conception stage to death (Shaffer, D. W., \& Resnick, M, 1999). Developments related to the biological maturity of a child must be in a condition in accordance with the age. The typical pattern that occurs at each stage of age is called normative development and the development of ideographic development (Tina Bruce, 1996). This stage is then known as the normative development standard which is assumed to be a universal pattern of developmental tasks that must be passed by a child. The development of education and parents about the task of child development can be obtained from direct experience and the search for various information. Understanding of child development tasks is necessary so that teachers and parents provide appropriate assistance and stimulation to children. Broadly speaking, the characteristics of the social-emotional, cognitive, and physical development of children in the age of the Play Group are as follows

a. Physical Development Aspect

1) Already able to walk alone, tiptoe, and jump

2) Start trying to go up and down the stairs even though they still have to be guided

3) Start wearing their own clothes

4) Can pedal a tricycle

5) Start eating with a spoon and fork even though sometimes it still spills.

b. Cognitive development aspect
1) They know their names, imagine, use simple sentences.

2) Love to sing simple songs

3) Recognize sounds that are often heard without seeing the object

4) Hearing simple stories with enthusiasm

5) Love stories that are known and read repeatedly

c. Social-emotional development aspect In the age of the Play Group children have various desires, always observing, seeing and imitating. The age of the Play Group is a stage with a desire for independence. Other emotional social-emotional characteristics include:

1) Seeking attention and consent of adults

2) Receive simple directions

3) Love to play alone but with close positions of their peers

4) Become an observer and monitor various things

5) Start showing emotion as expected or accepted by the social environment.

In general, the characteristics of children of the playgroup age are characterized by several periods that directly or indirectly affect how an educator should deal with early childhood. The following are the periods and how educators should respond to those periods.

a. Sensitive period

Most educators and parents have not been fully able to create a conducive condition, which is to provide opportunities and play certain games that can trigger the emergence of the sensitive period or develop the potential of children who have entered a critical or sensitive period.

b. Egocentrism period

Parents and educators must understand those playgroup age children are still in an egocentric period characterized by as if every action taken by children is the always 
correct, every wish must always be obeyed and they always want to win. As a teacher and parents can give children a gradual understanding so that children can become good social beings.

c. Mimicking period

At this time, the process of mimicking everything around them seemed to increase. This imitation is aimed at the children by imitating or following the attitudes of behavior, actions, and words of the people around them and cartoon movie characters or the soap opera actors who aired on television. Therefore (teachers and parents) must be able to become a role model and example for children in behaving, behaving and speaking words.

\section{d. Group period}

Educators must facilitate and provide opportunities for children by letting children play outside the home with their peers, not too restricting children in relationships so that children can later socialize and adapt according to behavior in their social environment. But educators still have to monitor and monitor the social environment in which the child gets along and knows the life of the group.

e. Exploration period

This period is a manifestation of the characteristics of playgroup age children who have great curiosity. Therefore educators must understand the importance of exploration for children. Educators must be able to facilitate and provide opportunities for children to channel their curiosity by letting children explore and try (trial and error) because children are excellent explorer.

f. Defiance period

Parents and educators are advised to simply admonish lovingly if the children are in a deviant condition. This is because the period of insubordination is a natural phase experienced and will be passed by all children aged 3-5 years. In addition, if there is defiance, the children should be given time for cooling down. For example in the form of stopping the activity and letting the children themselves be in their room or in a corner. Sometime later, the children are given advice about why he should do this.

\section{Art as an Early Childhood Learning Media}

Various media must be arranged in such a way that children can see that choices are available and ready and easily accessible. Sensitive motivation, teaching and guiding lead children to develop awareness about the various techniques and processes that may be through various media and add to the understanding of the structure of visual arts and functions by using these elements in their creations.

\section{a. Draw}

Children aged three, four to five years are entering the level of art and thinking of making symbols, so drawing is the single most important art activity. Every day, children must be able to draw. Of course, children need something to draw, and this is easy. Where are there things that can be observed, seen and focused so that children can draw. One class in an industrial city in the north of the country is filled with doves perched on window frames in winter. Yes, adults think the dove is a mess, but the children watch the bird for a year, the picture of their dove becomes more detailed. The children watch and draw the eyes, beaks, feathers, and legs of the dove. They compare with other birds. Pictures and also their learning is amazing.

\section{b. Coloring}

Children aged 3-5 years will draw in the same way as they doodle using crayons and paper. Children will fill the page with watercolors. Entered by the painting itself, they will continue to paint until the paper is really full. After they develop control over the painting, children will paint in the same way as they draw. They will use the same oval/ovoid 
symbols to bring people and stars and the same pattern for buildings and other objects. Because they work with watercolors and brushes, these symbols are less detailed than the symbols they draw.

Painting a bus is performed anywhere. You can prepare six when the paint box in the can of used yogurt is used by children to paint in board. The paint must be shiny and strong and the mixture is thick. Light and colored paint bring little interest in children. Mixing a little paint every day can guarantee freshness. Mixed colors allow children to present their experiences. One group visited yellow and red beekeepers so they could paint the bees they had observed. Other classes wander around the stairs to see all the fruit trees which bloom on the spring day. The teacher provides all types of paper and pink, lavender, and white paint. Don't let them draw with their ideas about the trees that were observed, but the resulting paintings illustrate the focus of children on trees and their ability to use the media in various ways to reflect their experiences.

\section{c. Make a Model}

There are no real activities like using clay. Punching, piercing, and pressing clay and creating three-dimensional objects is very satisfying and enjoyable. In addition, this activity also provides valuable experiences to all children, especially to those who need strengthening muscle movements. Clay does require special care. It must be stored carefully, and keep enough moisture to keep it in check. Trash cans or buckets where diapers are kept tightly closed are good storage places. The shape of the clay is as small as the size of a fist and punctures until it penetrates the clay fist in such a way that moisture seeps throughout the clay ball. Cover the clay with a damp towel. Place cartons or pieces of cloth which is not absorbing water near storage cans. Children can take a clay ball and board or on the table to work with clay.

Take a little clay and find what you can do with it. Bend the tusk and form the clay into several objects. You can form both an animal's eyes or both ears by using pointed objects in the clay, and you can make your feet by pulling out parts of the clay form. Make a ball from the clay, place both of your thumbs in the middle, and stretch it out to form a bowl or pot. If you want the bowl handle that you have made, there is a need to rough the two sides that you want to connect and moisturize them with a graft, which will act as an adhesive.

\section{d. Collage}

Collage, with its fast and patterned products, having three-dimensional effects, is a favorite of children aged 3-5 years. This collage is an art form where tapping the object is glued to a flat surface to convey the idea or feeling of making an experience. Light materials such as paper and cloth can be affixed to ordinary building paper or cardboard.

Any object can be used to make collages. Children can be selected from the 'junk box' or 'magic box' containing updated wrapping materials by removing the unused ones and replacing them with new and interesting objects. When children begin to make collages, with any media, they will scribble on irregular objects on paper. Collages will be more valuable if children collect their own ingredients. Go for a walk with the aim of collecting ingredients to make natural collages. Collage of a classroom or playground can be made from packaging materials found in the room or in the yard.

\section{e. Listen to music developing}

Everyone, at any age, can enjoy, listen to music. All they need to do is pay attention, feel, relax, and be happy. If children aged 3-5 years have enough experience with music, then they can listen attentively, capture the sounds of instruments by listening. They like to make their own sounds when they listen to music, apply the concept of hard, smooth, happy, sad, light, heavy, fast, or soft.

\section{Playing while learning sciences}

Learning is an approach in carrying out learning activities in children of kindergarten age. For that, in providing education to 
children in kindergarten, it must be done in a pleasant situation so that the child does not feel bored following the learning. Through children's play activities are invited to explore, discover and use objects that are close to them, so that learning becomes more meaningful.

Playing while learning science is an activity carried out with or without using a tool that produces understanding or provides information, gives pleasure, or develops children's imagination and causes changes in behavior that occur due to interactions between individuals and their environment. Benefits of playing while learning science on aspects of child development, including:

\section{a. Rough and Fine Motor}

\section{Development Aspect}

Various studies show that playing allows children to move freely so that they can develop their motor skills such as climbing, stepping, jumping, swinging, and so on.

\section{b. Cognition Development Aspect}

According to Piaget (1970) children will understand knowledge through interaction with objects in the surrounding environment. When playing while learning science, children have the opportunity to know the properties of objects by observing through touching, kissing and listening

\section{c. Social Development Aspect}

When children are playing with science, children can learn to socialize and group so that they open up opportunities to interact with others. This interaction teaches children how to respond, give and receive, reject and approve other ideas or behaviors.

\section{d. Language Development Aspect}

When children play while learning science, the child is trained to present answers which means that the child practices to use language in order to communicate and expresses the idea or thought.

\section{e. Moral Development Aspect}

Each game has rules, rules will be introduced by friends, step by step until the child understands the rules of play. Therefore, playing will train the children to be aware of the rules and the importance of understanding the rules, this is an initial stage of moral development.

According to Suyanto (2005: 158), the introduction of science to early childhood education is carried out to develop the following abilities:

a. Exploration and investigation

b. Develop basic process skills, such as observing, measuring, communicating observations.

c. Develop curiosity, feeling happy, and willing to do inquiry or discovery activities.

d. Understand knowledge of objects, both their characteristics, structure and function.

From the above, the study of science in kindergarten can be designed through what includes activities to observe, investigate, process skills, and arouse children's curiosity.

\section{Utilization of Media in Early Childhood Education}

Some learning that can utilize multimedia where appropriate to the characteristics of early childhood are as follows:

a. Playing Activity Method

The world of children is playing, Akselrod et al. (1985: 266) argued that play is a work of childhood - a mirror of child growth.

According to Moeslichatoen (2003: 32) playing is a demand and psychological and biological needs of children who are very essential. Through play, demands for the developmental needs of the motoric dimension, cognition, creativity, language, emotion, social interaction, values and attitudes of life can be fulfilled. When playing, the child imagines, and issues ideas stored in him. Children can express the 
knowledge they have about the world and at the same time can gain new knowledge, and all are done in a heartening way.

Playing as a form of learning activities in kindergarten is a creative and fun play. In addition, playing can provide opportunities for children to develop imagination and practice their creativity. Sudono (2000: 1) said that playing can also improve communication skills and provide more opportunities for children to explore, so that understanding of basic concepts and understanding of knowledge can be understood by children more easily.

b. Storytelling Method

The method of storytelling is one form of learning experiences for children in kindergarten. By presenting the story orally either by reading directly from the book or by using picture illustrations or using puppet displays that can increase the child's imagination. Through the storytelling method, children are trained to be critical and creative listeners. Another benefit that can be felt from this method is that it can train concentration and capture power and build the child's imagination development.

\section{c. Demonstration Method}

The demonstration method is a way to show and explain ways to do things. Demonstration methods can also improve children's thinking, especially in improving the ability to recognize, remember and think critically and creatively. With the demonstration method, the teacher can remind understanding through vision and hearing. This method is useful for providing illustrations and explaining something inconvenient or events to the child.

\section{d. Project Method}

The project method is the provision of learning experience by giving children problems or everyday problems that must be solved in groups. The benefit of this method is being able to improve the skills that have been owned and provide opportunities for children to realize their creative power.

e. Assignment Method

The assignment method is a way of providing learning experiences by giving assignments that are deliberately given to children. The benefits of this method are to improve the way of learning better and to strengthen the mastery of the acquisition of learning outcomes. For example, students are asked to connect pictures with objects. It should be noted that the task given is in accordance with the stage of child development.

\section{Material of Early Childhood Education}

Multimedia is a product and process. As a product, multimedia is a well-organized body of knowledge about the physical and natural world. As a process, multimedia is an activity of tracing, observing, and conducting experiments. There are several types of skills that can be trained in early childhood. First, the children are invited to observe natural phenomena that occur in the child's environment. Second, is the skill of grouping objects according to their category. Third, estimate. Children are asked to estimate what will happen. Fourth, counting. Children are encouraged to count objects around them, then introduce objects to them. Some concepts that early childhood can learn by using multimedia are as follows:

a. Identify objects around them by size (measurement), such as weighing, measuring and measuring.

b. The balloon is blown and then released, the air moves.

c. Objects inserted into the water (floating, floating, sinking).

d. Objects that are dropped (gravity).

e. Experiment with magnets.

f. Observe with a magnifying glass. 


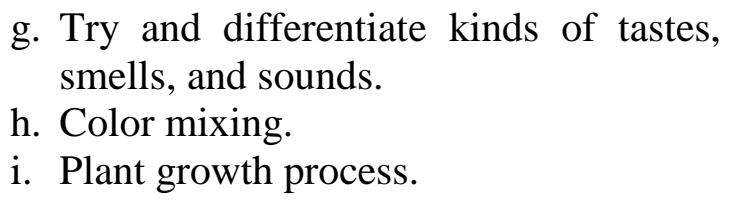

\section{Learning Resources and Playing Tools}

Learning resources are materials including tools to provide information and skills to students and teachers to gain knowledge and enrich knowledge that can take the form of reference books, story books, media tools, cooking utensils, carpentry tools, and cultural objects. Learning media for children is generally in the form of materials and game tools. According to Gordon and Browne (1985: 214) materials and game equipment for children should:

a. Able to invite attention and attract children's interest.

b. Can meet various objectives of developing all aspects of development.

c. Can expand children's opportunities to use them in various ways.

d. Reflect the characteristics of the age group of children.

e. In accordance with the curriculum used.

f. Reflecting the quality of design and work skills.

g. Durable.

h. Can be used flexibly and versatile.

i. Easy to care for and repair.

j. Reflecting an increase in group culture.

k. Does not distinguish gender.

\section{Benefits of Multimedia in Early Childhood Education}

a. Increasing Curiosity and Student Learning Activities

By utilizing science teaching tools, children's activities will increase, initially, the children only pay attention to the material in the form of the theory presented by the teacher, after using teaching tools, the children can find some scientific concepts and experiment or observe. b. Clarifying the Presentation of Learning Materials

By using teaching tool as a medium of learning, the material of science that is conveyed is clearer, with concrete evidence. For example, is mixing colors, by mixing colorful colors, children can see concrete changes in color.

c. Solve the limitations of space, time and power of the senses

Teaching tools become a bridge between theory in class and the actual situation. By using teaching tools both can be obtained in one experiment, with students experimenting, the teacher does not need to explain again about the material, the teacher only discusses and adds or analyzes if there is a wrong concept.

d. Learning outcomes are more permanent or steady

With an experiment and finding own concepts, children will be easier to remember the information obtained and not forget quickly.

e. Helping Children Who Are Missing Lessons

The use of teaching tools can help students who are rather slow in learning. With the existence of concrete evidence, the child will understand better, for example observing the form of refraction and a convex lens.

f. Increasing Interest and Attention of Children

By experimenting with teaching tools, the child's attention will be more focused on the experiment.

\section{Practicing Critical Thinking Ability through Science Learning}

Science is a branch of knowledge that aims to study and understand events or natural phenomena that occur in the environment around. Introducing science concepts to children can be performed by playing activity. In the playing activity, children are invited to experiment. If a children test something that 
provokes their curiosity, they actually have tried to practice critical thinking. Thus, the application of the playing method with a play while learning approach can increase the opportunity for children to practice their thinking skills both in the ability to think critically and creatively and learn various kinds of simple concepts.

In implementing the learning activities that apply the playing method, the Daily Activity Unit (SKH) can be prepared. This Daily Activity Unit (SKH) contains the implementation of Science learning activities with a play while learning approach. While students' thinking ability can be known and observed from the evaluation sheet containing questions. These questions can be used to determine the child's thinking ability both the ability to think critically and creatively.

Yulianti et al (2014) research results showed that the Kindergarten learning model by playing while learning can train the ability to think critically and creatively. Critical thinking skills are trained, including the following:

\section{a. Finding Possibilities}

Children can be invited to find possibilities - for example, children are asked to look for falling objects even though the direction of dropping objects is different.

b. Finding an error

Children can be taught to find mistakes by using pictures, for example, children are given a picture that is incomplete Then the child is asked to find an error in the picture.

c. Distinguishing Facts and Opinions Children can be taught to distinguish a statement that is a fact or opinion, for example, children are asked to determine a measurement tool that is more useful or useful for measuring length.

d. Estimating the Cause

Children can be trained to look for objects made to influence gravity and objects made to counter gravity. For example, children are trained to find out why fish can be hooked by connecting images or coloring pictures.

e. Making decision

In the training of decision-making ability, children are trained to make decisions when facing problems.

\section{Conclusion}

Early childhood education is actually a shared responsibility between family, community, and government. Schools as helpers for continuing education in the family, because first and foremost education is obtained from families. Therefore learning art is very important and good for honing children's creativity to develop the skills they want.

\section{Daftar Pustaka}

Akselrod, S., Gordon, D., Madwed, J. B., Snidman, N. C., Shannon, D. C., \& Cohen, R. J. (1985). Hemodynamic regulation: investigation by spectral analysis. American Journal of Physiology-Heart and Circulatory Physiology, 249(4), H867-H875.

Bruce, T. (1996). Helping young children to play. Hodder \& Stoughton.

Gordon, A. M., \& Browne, K. W. (1985). Beginnings and beyond: foundations in early childhood education. Delmar Publishers.

Piaget, J. (1970). Science of education and the psychology of the child. Trans. D. Coltman.

Shaffer, D. W., \& Resnick, M. (1999). " Thick" Authenticity: New Media and Authentic Learning. Journal of interactive learning research, 10(2), 195-216.

Sirna, I. W., \& Dewi, P. E. R. (2018). Pemanfaatan Multimedia Presentasi Dan Media Cetak Dalam Meningkatkan Mutu Pembelajaran Pendidikan Agama Hindu. Jurnal Penjaminan Mutu, 4(1), 115-130.

Sudono, A. (2000). Sumber belajar dan alat permainan untuk pendidikan anak usia dini. Jakarta: Grasindo. 
Suyanto, S. (2005). Dasar-dasar pendidikan anak usia dini. Yogyakarta: Hikayat Publishing.

Yulianti, D., Rida, N. S., \& Diana, D. (2014). Pengembangan Karakter Peduli Lingkungan Anak Usia Dini Melalui Buku Cerita Bermuatan Sains Berwawasan Konservasi. Jurnal Penelitian Pendidikan, 31(1). 